\title{
Effectiveness of ligation of uterine vessels prior to uterine incision for major placenta previa on reducing maternal morbidity without increasing neonatal morbidity
}

\author{
Shantha V. K.*, Priyadarshini M., Priya Dharshini A., Litty Mariyam Jacob
}

Department of Obstetrics and Gynecology, Sundaram Medical Foundation, Chennai, Tamil Nadu, India

Received: 04 May 2018

Accepted: 29 May 2018

*Correspondence:

Dr. Shantha VK,

E-mail: shanthavk2015@gmail.com

Copyright: $($ the author(s), publisher and licensee Medip Academy. This is an open-access article distributed under the terms of the Creative Commons Attribution Non-Commercial License, which permits unrestricted non-commercial use, distribution, and reproduction in any medium, provided the original work is properly cited.

\section{ABSTRACT}

Background: Placenta previa causes massive obstetric haemorrhage and severe maternal morbidity. The objective is to analyse the effectiveness of uterine vessels (artery and vein) ligation before uterine incision in reducing blood loss and hysterectomy during caesarean section for major placenta previa without increasing morbidity in the newborn.

Methods: A retrospective analysis of caesarean section for major placenta previa from 2002 to 2017 was done. Uterine vessels ligation before uterine incision was done in 52 patients. In 19 patients unilateral and in 33 patients bilateral uterine vessels ligation was done before uterine incision. In control group, 12 patients with major placenta previa uterine vessels were ligated after the removal of the placenta. The blood loss, blood transfusion, maternal morbidity and NICU admission of the newborns were compared.

Results: The mean blood loss was $1002 \mathrm{ml}$ in unilateral, $793 \mathrm{ml}$ in bilateral uterine vessels ligation group, compared to $2191 \mathrm{ml}$ in the control group. The mean blood transfusion volume 0.89 units in unilateral 0.60 units in bilateral ligation group while 2.33 units in the control group. The difference in blood loss and blood transfusion were statistically significant. Out of 52 babies, only 6 babies were admitted in NICU for mild depression with stay less than 3 days.

Conclusions: Uterine vessels ligation before uterine incision reduces blood loss and hysterectomy during caesarean section for placenta previa without increasing the morbidity in the newborns.

Keywords: Blood transfusion, Caesarean hysterectomy, Obstetric haemorrhage, Placenta previa, Uterine artery and vein ligation

\section{INTRODUCTION}

Obstetric haemorrhage continues to be the leading cause for maternal morbidity and mortality despite major improvement in obstetric care and blood transfusion services. Postpartum haemorrhage accounts for $34 \%$ of maternal mortality in developing countries. ${ }^{1}$ Uterine atony and abnormal placentation are the most common causes of massive obstetric haemorrhage and obstetric hysterectomy. ${ }^{2}$ Securing haemostasis is the major challenging task for the obstetrician in these cases. ${ }^{3}$
Placenta previa is the most common abnormal placentation associated with severe haemorrhage. Placenta is situated in the fundus of the uterus in normal conditions. When the placenta is situated in the lower segment it is termed as placenta previa and when it completely covers the internal cervical os, it is described as major degree of placenta previa. The separation of placenta previa is associated with severe bleeding as the lower uterine segment does not contract and if the bleeding is uncontrollable it ends up in hysterectomy. Severe postpartum haemorrhage, massive blood 
transfusion, disseminated intravascular coagulation (DIC) and caesarean hysterectomy are the dreaded maternal complications expected. ${ }^{4,5}$ Perinatal morbidity and mortality increases with placenta previa due to preterm birth, low APGAR score, low birth weight and congenital malformation. ${ }^{4,6,7}$ Neonatal respiratory distress syndrome, neonatal intensive care unit (NICU) admission and prolonged hospital stay are also associated with placenta previa. ${ }^{7}$ When there is no cleavage between myometrium and placenta it is called placenta accreta. Placenta increta and percreta are abnormal placentation where placenta is invaded into the myometrium/serosa. Direct hysterectomy with placenta in situ is the management option available in such situations. ${ }^{8}$ History of previous caesarean section with placenta previa also increases the risk for caesarean hysterectomy. ${ }^{9}$

Placenta previa is usually diagnosed by ultrasonography (USG) during 20 to 22 weeks of gestation. A repeat scan at 30 to 32 weeks is indicated for confirming the placental position and to plan the delivery. Studies have proven that transvaginal ultrasound is more accurate in diagnosing placenta previa. It is safe, cost effective, well tolerated and superior to trans abdominal scan (TAS). ${ }^{10,11}$ When ultrasound examination is inconclusive magnetic resonance imaging $(\mathrm{MRI})$ is the modality that helps to differentiate abnormal placentation. ${ }^{12}$ For an uncomplicated placenta previa an elective caesarean section can be planned between 36 to 37 weeks of gestation age. If severe obstetric haemorrhage is encountered during caesarean section, massive transfusion protocol has to be activated. ${ }^{13}$ Various measures are being practiced to reduce the blood loss during caesarean section. Uterine artery ligation and internal iliac artery ligation are the surgical procedures used to control the haemorrhage and to conserve the uterus. ${ }^{14}$ Compression sutures, Bakri balloon tamponade, packing the lower segment with gauze are some of the other methods used to control placental bed bleeding. ${ }^{15-18}$ With advances in interventional radiology, techniques like prophylactic internal iliac artery balloon catheterization and uterine artery embolization are used before the delivery of the placenta. Limited availability of expertise and the cost preclude its regular use. ${ }^{19,20}$ Conventionally uterine artery ligation is done after the delivery of the placenta for severe uncontrollable obstetric haemorrhage. A newer approach of ligating uterine vessels (both artery and veins) even before lower uterine segment incision is followed in our institution for more than 10 years. The aim of this retrospective analysis is to assess the effectiveness of this procedure in reducing blood loss and hysterectomy without increasing the morbidity in the newborn.

\section{METHODS}

This is a retrospective analysis of the patients with major degree placenta previa who underwent caesarean section at Sundaram Medical Foundation, Dr Rangarajan Memorial Hospital, Chennai, Tamilnadu, South India, from January 2002 to Dec 2017. Data collection was done from the patient's inpatient records.

\section{Evolution of surgical technique}

During the earlier period of this analysis, ligation of the uterine vessels (artery \& veins) after the delivery of the baby and the placenta was the practice adopted. As the intra-operative bleeding was heavy, requiring multiple units of blood transfusion, we started ligating the uterine vessels before the uterine incision. Initially unilateral and later on bilateral uterine vessels were ligated before uterine incision. This was found to be associated with reduced amount of haemorrhage and blood transfusions. 52 patients with major degree placenta previa underwent uterine vessels ligation before uterine incision. Among which 19 patients underwent unilateral ligation (group A) and 33 patients underwent bilateral ligation (Group B) prior to uterine incision. 12 patients with major degree placenta previa for whom uterine vessels were ligated after the removal of the placenta, were taken as controls.

\section{Preoperative preparations}

Same protocol was followed for all cases of placenta previa. Ultrasound examination was done to diagnose and confirm the type of placenta previa. MRI scan was done when there was suspicion of placenta accreta especially in cases of previous caesarean section or when USG was inconclusive. Once major placenta previa was diagnosed, the patient and the caretakers were counselled regarding the risk of unexpected bleeding, requirement of multiple units blood transfusion and the chances of obstetric hysterectomy during caesarean section. Asymptomatic cases were planned for elective caesarean section between 37 and 38 weeks. Women with previous bleeding episodes were posted for caesarean section at 36 weeks to prevent unexpected massive haemorrhage. Steroid coverage was given for preterm cases. When patients present with severe bleeding and/or pains, they were taken up as emergency caesarean section irrespective of gestational age. On the day of surgery ultrasound examination was repeated to recheck the position of bulky portion of the placenta (central/anterior/posterior). The presentation of the foetus was confirmed especially in non cephalic presentation, to effect quick delivery of the foetus. Availability of 6-8 units compatible packed red blood cells and fresh frozen plasma was confirmed and reserved. General anaesthesia was preferred to face massive haemorrhage. For cases where massive haemorrhage was anticipated like previous caesarean with placenta on the scar or anterior placenta where placenta had to be cut through to deliver the baby, bilateral uterine vessels ligation was adopted.

\section{Consent for surgery}

Consent was obtained for caesarean section, transfusion of multiple units of red blood cell and other blood products. Consent was also obtained for measures 
required to control bleeding and for hysterectomy in case of uncontrolled haemorrhage. Possibility for injury to bladder in cases of placenta accreta/percreta and involvement of urologist in case of bladder injury, ICU admission for the patient and NICU admission of the newborn in case of complication were also included in the consent.

\section{Surgical technique}

After opening the abdomen by pfannenstiel incision, uterovesical fold of peritoneum cut opened and pushed down. Lower uterine segment exposed. Two methods of uterine vessels ligation were followed.

\section{Method 1}

Before the delivery of the baby the uterine vessels are prominent and easy to hold the branches together with Babcock forceps than after the delivery of the baby. Surgeon's left hand was inserted behind the broad ligament and uterine vessels on the lateral side of lower uterine segment lifted up (Figure 1) and held with Babcock forceps (Figure 2). No 1 chromic catgut was used to take the sutures, with the needle passing through the outer myometrium (Figure 3); above and below the Babcock forceps on both sides with $2 \mathrm{~cm}$ gap in between. The knots were laid on either sides (Figure 4) but not ligated at this point of time. The side where the bulk of the placental mass is situated was tied first (Figure 5). The uterine incision was made, and the baby was delivered. Then the opposite side sutures which were laid and kept was ligated. Placenta was separated from lower segment and placental bed haemostasis secured by sutures.

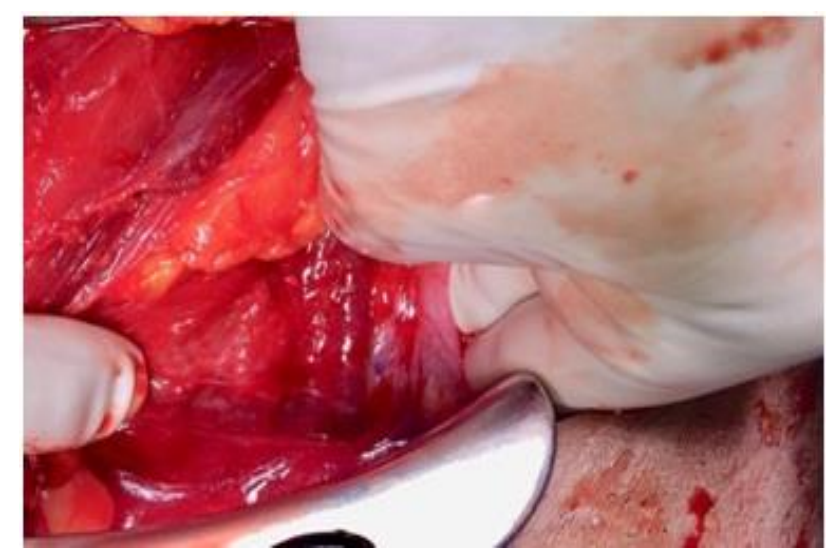

The blood vessels are turgid before the delivery of the baby. By lifting up from behind, all vessels were seen clearly and any bowel under the broad ligament was protected while taking stitches.

Figure 1: Uterine vessels were lifted up with fingers posteriorly.

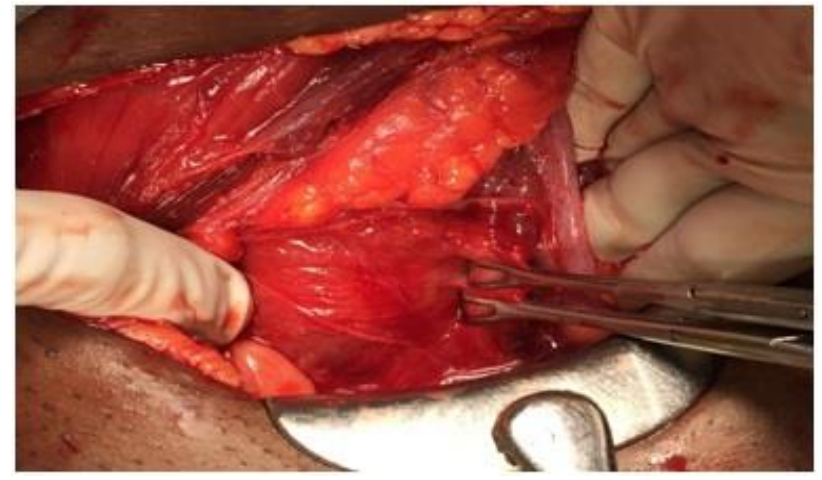

Non-traumatic Babcock forceps were used to hold all the branches together and made it easier to take the stitch with the needle.

Figure 2: Holding uterine vessels bunch with Babcock forceps.

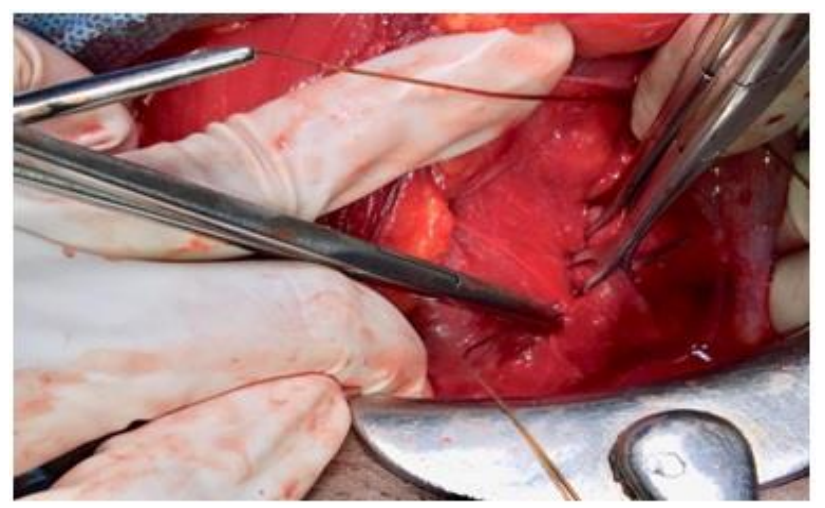

Figure 3: Taking stitch under uterine vessels.

No-1 chromic catgut was used to take the stitch. Two sutures were placed $2 \mathrm{~cm}$ apart above and below the forceps. Sutures were taken through the outer $1 / 3$ of myometrium under uterine vessels. Same step was done on the opposite side.

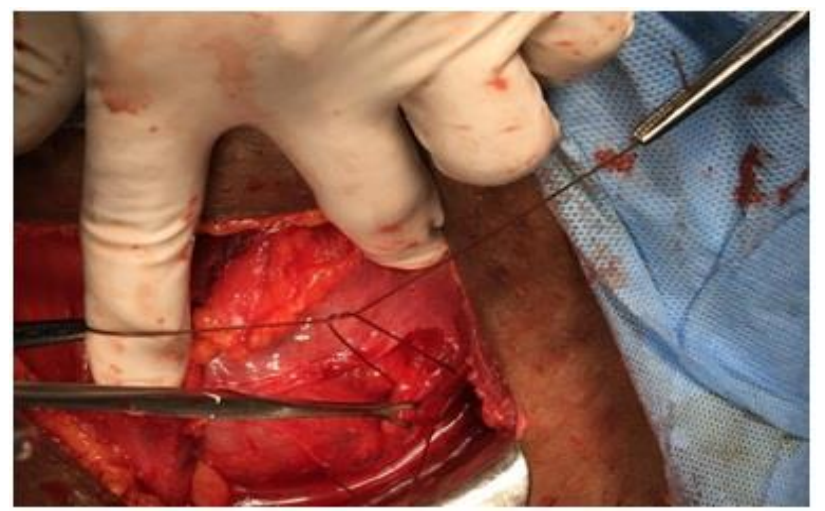

Figure 4: Laying the knot.

The knots were laid, two knots on either side uterine vessels. But not ligated at this point. 


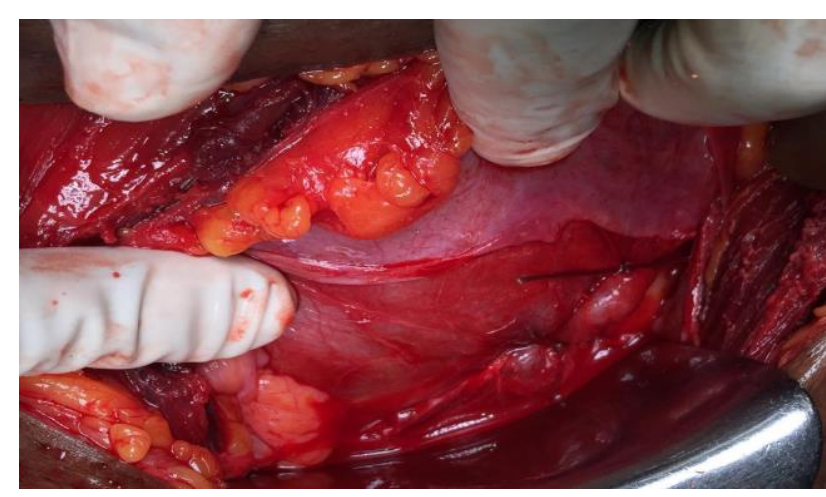

Figure 5: Uterine vessels ligated.

During method 1, unilateral vessels were tied before uterine incision and the opposite side vessels were ligated soon after the delivery of the baby. In method 2, knots were tied on either side and then the uterine incision was made. If needed the incision can be extended between the knots when the lower segment is narrow as in preterm cases.

\section{Method 2}

The ligatures were laid on both side uterine vessels as mentioned in method 1 . The knots were tied at the same time on both sides prior to uterine incision and transverse incision was made in the lower uterine segment. In preterm patients where lower segment was not formed and narrow, the incision was extended laterally between the ligatures and the baby was delivered quickly. Placenta was separated from lower segment and haemostasis was secured by sutures. In case of anterior placenta previa, cutting through the placenta was avoided. After incising the myometrium, placental cotyledons were separated by fingers up to the membranes which were cut open and the baby was delivered. The time interval from vessel ligation to delivery of the baby was very less, approximately $1 \frac{1}{2}$ minutes (duration of time was noted from video recording of the procedure). One of the above two methods was adopted depending on intra-operative findings. When more bleeding is anticipated like anterior placenta and/or dilated vessels running on the lower segment and in cases of previous caesarean section, method 2 was preferred to reduce the blood loss. Uterotonics were used along with surgical techniques. Blood loss was assessed by counting the surgical pads soaked with blood and the blood collected in the suction bottle, a near accurate method, as the abdomen drapes used were non-absorbable and the dry pads used once were not reused. The blood loss was documented by anaesthesiologists in their records. Paediatrician was present to receive the baby soon after the delivery, and to assess the APGAR score and the status of the baby. Preterm babies and the babies depressed at birth were admitted to NICU.

\section{Statistical methods}

Data analysis was done using SPSS version 19.0. Descriptive statistics were calculated for background variables. ANOVA test was done to compare the significance in quantitative data between three groups. Chi-square test was done to compare the difference in proportion. $\mathrm{P}$-value is considered significant of $\mathrm{P}<0.05$.

\section{RESULTS}

There were 52 patients in this study. In group A, 19 patients underwent one sided uterine vessels ligation before uterine incision and the opposite side ligation was done after the delivery of the baby (method 1) and in group B, 33 patients underwent uterine vessels ligation on both sides before uterine incision (method 2$)$.

Table 1: Demographic and obstetric details.

\begin{tabular}{|c|c|c|c|c|c|}
\hline \multirow{2}{*}{$\begin{array}{l}\text { Demographic } \\
\text { details }\end{array}$} & \multirow{2}{*}{ Variable } & \multicolumn{2}{|c|}{$\begin{array}{l}\text { Uterine vessels ligation before uterine } \\
\text { incision ( } \mathrm{n}=\mathbf{5 2} \text { ) (Study group) }\end{array}$} & \multirow{2}{*}{$\begin{array}{l}\text { Uterine vessels ligation } \\
\text { after removal of } \\
\text { placenta } \\
(\mathrm{n}=12) \text { (Control group) }\end{array}$} & \multirow{2}{*}{ P Value } \\
\hline & & $\begin{array}{l}\text { Unilateral } \\
\text { N=19 (Group A) }\end{array}$ & $\begin{array}{l}\text { Bilateral } \\
\mathbf{N}=33 \text { (Group B) }\end{array}$ & & \\
\hline \multirow{3}{*}{ Age (years) } & $<30$ & $11(57.89 \%)$ & $24(72.72 \%)$ & $4(33.3 \%)$ & \multirow{2}{*}{$0.638(\mathrm{NS})$} \\
\hline & $>30$ & $8(42.10 \%)$ & $9(27.27 \%)$ & $8(66.7 \%)$ & \\
\hline & Mean Age & $30 \pm 4$ & $29 \pm 5$ & $31 \pm 5$ & 0.469 (NS) \\
\hline \multirow{2}{*}{ Parity } & Primi & $14(73.68 \%)$ & $13(39.39 \%)$ & $2(36.5 \%)$ & \multirow{2}{*}{$0.188(\mathrm{NS})$} \\
\hline & Multi & $5(26.31 \%)$ & $20(60.60 \%)$ & $10(63.5 \%)$ & \\
\hline \multirow{4}{*}{$\begin{array}{l}\text { Gestational age } \\
\text { (weeks) }\end{array}$} & $<34$ & $2(10.52 \%)$ & $9(27.27 \%)$ & $1(8.33 \%)$ & \multirow{3}{*}{$0.545(\mathrm{NS})$} \\
\hline & $34-37$ & $8(42.10 \%)$ & $14(42.42 \%)$ & $6(50 \%)$ & \\
\hline & $>37$ & $9(47.36 \%)$ & $10(30.30 \%)$ & $5(41.67 \%)$ & \\
\hline & Mean GA & $36 \pm 2$ & $35 \pm 3$ & $37 \pm 2.3$ & $0.288(\mathrm{NS})$ \\
\hline \multirow{4}{*}{$\begin{array}{l}\text { Risk factors for } \\
\text { hemorrhage }\end{array}$} & Previous LSCS & $4(21.05 \%)$ & $11(33.33 \%)$ & $6(50 \%)$ & \multirow{4}{*}{$0.873(\mathrm{NS})$} \\
\hline & Adherent placenta & $3(15.78 \%)$ & $2(06.06 \%)$ & $1(8.33 \%)$ & \\
\hline & Placenta increta & 0 & $1(03.03 \%)$ & 0 & \\
\hline & Anterior placenta & $5(26.31 \%)$ & $8(24.24 \%)$ & $4(33.33 \%)$ & \\
\hline \multirow{2}{*}{$\begin{array}{l}\text { Mode of } \\
\text { delivery }\end{array}$} & Elective LSCS & $15(78.94 \%)$ & $16(48.49 \%)$ & $10(83.33 \%)$ & \multirow{2}{*}{$0.048(\mathrm{~S})$} \\
\hline & Emergency LSCS & $4(21.05 \%)$ & $17(51.51 \%)$ & $2(16.67 \%)$ & \\
\hline
\end{tabular}


Table 2: Blood loss and blood transfusion.

\begin{tabular}{|c|c|c|c|c|c|}
\hline & \multirow{2}{*}{ Variables } & \multicolumn{2}{|c|}{$\begin{array}{l}\text { Uterine vessels ligation before uterine } \\
\text { incision ( } \mathrm{n}=52 \text { ) (Study group) }\end{array}$} & \multirow{2}{*}{$\begin{array}{l}\text { Uterine vessels ligation after } \\
\text { removal of placenta } \\
(n=12) \text { (Control group) }\end{array}$} & \multirow{2}{*}{ P Value } \\
\hline & & $\begin{array}{l}\text { Unilateral } \\
\text { N=19 (Group A) }\end{array}$ & $\begin{array}{l}\text { Bilateral } \\
\text { N=33 (Group B) }\end{array}$ & & \\
\hline \multirow{5}{*}{$\begin{array}{l}\text { Blood loss } \\
(\mathrm{ml})\end{array}$} & $\leq 1000$ & $15(78 \%)$ & $27(81 \%)$ & $1(8.33 \%)$ & \multirow{4}{*}{$0.000(\mathrm{~S})$} \\
\hline & $>1000-1500$ & $2(10.5 \%)$ & $4(12.1 \%)$ & $3(25.00 \%)$ & \\
\hline & $>1500-2000$ & 0 & $1(3 \%)$ & $4(33.33 \%)$ & \\
\hline & $>2000-4000$ & $2(10.5 \%)$ & $1(3 \%)$ & $4(33.33 \%)$ & \\
\hline & Mean & 1002 & 793 & 2191 & $0.000(\mathrm{~S})$ \\
\hline \multirow{6}{*}{$\begin{array}{l}\text { Blood } \\
\text { transfusion } \\
\text { (units) }\end{array}$} & Nil & $11(57.89 \%)$ & $21(63.63 \%)$ & $4(33.33 \%)$ & \multirow{5}{*}{$0.002(\mathrm{~S})$} \\
\hline & 1 & $2(5.26 \%)$ & $6(18.1 \%)$ & 0 & \\
\hline & 2 & $4(21.05 \%)$ & $4(12.1 \%)$ & $1(8.33 \%)$ & \\
\hline & 3 & $2(10.5 \%)$ & $2(6 \%)$ & $2(16.67 \%)$ & \\
\hline & 4 & $1(5.26 \%)$ & 0 & $5(41.67 \%)$ & \\
\hline & Mean & 0.89 & 0.60 & 2.33 & $0.001(\mathrm{~S})$ \\
\hline
\end{tabular}

The results were compared and analysed with 12 cases of the control group. The demographic and obstetric characteristics are given in Table 1 .

The difference in age, parity, gestational age and risk factors in study and control group were statistically not significant. Emergency caesarean sections were $21 \%$ in group A, $51.5 \%$ in group B when compared to $16.6 \%$ in control group. The blood loss was markedly reduced and the requirement for red blood cell transfusion also was less when uterine vessels were ligated prior to uterine incision. The mean blood loss was $1002 \mathrm{ml}$ in group A, $793 \mathrm{ml}$ in group B, while it was $2191 \mathrm{ml}$ in control group ( $\mathrm{P}$ value-0.000) (Table 2). The mean blood transfusion volume in the study group was 0.89 units in group $\mathrm{A}$, 0.60 units in group $\mathrm{B}$, while 2.33 units in the control group (P value- 0.001) (Table 2). The difference in blood loss and blood transfusion were statistically significant between the study and control group.

Duration of surgery was more than 2 hours in $16.67 \%$ of control group while no case was prolonged beyond $2 \mathrm{hrs}$ in the group A and group B where uterine vessels were ligated before uterine incision $(\mathrm{P}$ value 0.011$)$ and the difference was significant (Table 3 ).
Table 3: Duration of surgery.

\begin{tabular}{|c|c|c|c|c|}
\hline \multirow[t]{2}{*}{$\begin{array}{l}\text { Surgery } \\
\text { duration } \\
\text { (hours) }\end{array}$} & \multicolumn{2}{|c|}{$\begin{array}{l}\text { Uterine vessels } \\
\text { ligation before uterine } \\
\text { incision ( } \mathrm{n}=52 \text { ) (Study } \\
\text { group) }\end{array}$} & \multirow{2}{*}{$\begin{array}{l}\text { Uterine } \\
\text { vessels } \\
\text { ligation } \\
\text { after } \\
\text { removal of } \\
\text { placenta } \\
\text { ( }=12) \\
\text { (Control } \\
\text { group) }\end{array}$} & $\begin{array}{l}\text { P. } \\
\text { value }\end{array}$ \\
\hline & $\begin{array}{l}\text { Unilateral } \\
\mathrm{N}=19 \\
\text { (Group A) }\end{array}$ & $\begin{array}{l}\text { Bilateral } \\
\mathrm{N}=33 \\
\text { (Group } \\
\text { B) }\end{array}$ & & \multirow[t]{3}{*}{$\begin{array}{l}0.011 \\
\text { (S) }\end{array}$} \\
\hline $1-2$ & $19(100 \%)$ & $\begin{array}{l}33 \\
(100 \%)\end{array}$ & $10(83.33 \%)$ & \\
\hline$>2$ & 0 & 0 & $2(16.67 \%)$ & \\
\hline
\end{tabular}

There were two cases of hysterectomy $(3.84 \%)$ in the study group, one from group A for atonic PPH secondary to multiple fibroids and the second case was from group B- hysterectomy was done for placenta percreta with previous caesarean. It was an elective caesarean hysterectomy with placenta in situ. In the control group there were two cases of hysterectomy $(16.66 \%)$ done for uncontrolled bleeding.

Table 4: Maternal morbidity.

\begin{tabular}{|c|c|c|c|c|}
\hline \multirow{2}{*}{ Morbidity } & \multirow{2}{*}{ Causes } & \multicolumn{2}{|c|}{$\begin{array}{l}\text { Uterine vessels ligation before uterine } \\
\text { incision }(\mathrm{n}=\mathbf{5 2}) \text { (Study group) }\end{array}$} & \multirow{2}{*}{$\begin{array}{l}\text { Uterine vessels ligation } \\
\text { after removal of } \\
\text { placenta }(n=12) \text { (Control } \\
\text { group) }\end{array}$} \\
\hline & & $\begin{array}{l}\text { Unilateral } \\
\mathrm{N}=19 \text { (Group A) }\end{array}$ & $\begin{array}{l}\text { Bilateral } \\
\text { N=33 (Group B) }\end{array}$ & \\
\hline \multirow{3}{*}{ Hysterectomy } & Placenta percreta & 0 & $1(3.03 \%)$ & 0 \\
\hline & $\begin{array}{l}\text { Uterine atony and } \\
\text { fibroid uterus }\end{array}$ & $1(5.2 \%)$ & 0 & 0 \\
\hline & $\begin{array}{l}\text { Massive haemorrhage } \\
\text { from the placental bed }\end{array}$ & 0 & 0 & 2 \\
\hline \multirow{2}{*}{ ICU admission } & Massive bleeding & 0 & 0 & $1(8.33 \%)$ \\
\hline & Anaesthetic complication & 0 & $1(3.03 \%)$ & 0 \\
\hline
\end{tabular}


Table 4: Neonatal morbidity.

\begin{tabular}{|c|c|c|c|c|}
\hline \multirow{2}{*}{ NICU admission } & \multicolumn{2}{|c|}{$\begin{array}{l}\text { Uterine vessels ligation before uterine } \\
\text { incision ( } n=52) \text { (Study group) }\end{array}$} & \multirow{2}{*}{$\begin{array}{l}\text { Uterine vessels ligation after } \\
\text { removal of placenta ( } \mathrm{n}=\mathbf{1 2}) \\
\text { (Control group) }\end{array}$} & \multirow{2}{*}{ P-value } \\
\hline & $\begin{array}{l}\text { Unilateral } \\
\text { N=19 (Group A) }\end{array}$ & $\begin{array}{l}\text { Bilateral } \\
\mathbf{N}=\mathbf{3 3} \text { (Group B) }\end{array}$ & & \\
\hline For preterm care & $1(05.26 \%)$ & $11(33.33 \%)$ & $1(8.33 \%)$ & \multirow{5}{*}{$\begin{array}{l}0.372 \\
\text { (NS) }\end{array}$} \\
\hline $\begin{array}{l}\text { Depressed at birth } \\
\text { (transient) }\end{array}$ & $2(10.52 \%)$ & $4(12.12 \%)$ & $1(8.33 \%)$ & \\
\hline $\begin{array}{l}\text { Severe hypoxia and } \\
\text { mortality }\end{array}$ & Nil & Nil & Nil & \\
\hline Total NICU admission & $3(15.78 \%)$ & $15(45.49 \%)$ & $2(16.66 \%)$ & \\
\hline $\begin{array}{l}\text { Mean duration of stay in } \\
\text { NICU }\end{array}$ & 3 days & 3 days & 2 days & \\
\hline
\end{tabular}

One patient $(3.03 \%)$ was kept in ICU for one day observation as she developed desaturation during anaesthesia. Her blood loss was only $600 \mathrm{ml}$ and did not receive any transfusion. In the control group one patient $(8.33 \%)$ was admitted to ICU for uncontrolled haemorrhage (Table 4).

Of the 52 babies, 18 babies $(34.61 \%)$ were admitted to NICU, out of this 12 were preterm. One preterm newborn $(5.26 \%)$ from group A and 11 preterm $(33.33 \%)$ from group B were admitted for preterm care. Only 6 babies were admitted to NICU for mild depression, 2 from group A $(10.5 \%), 4$ from group B $(12.2 \%)$ with a stay of less than 3 days and returned to mother side (table 5). There was no case of severe hypoxia or with long term sequelae. Two babies $(16.66 \%)$ were admitted to NICU from control group for apnoea and preterm care.

27 patients $(55.5 \%)$ of the study group, had attended the hospital for various complaints after the caesarean section for placenta previa. Their menstrual function was recorded as normal. 7 patients $(25.92 \%)$ conceived, 5 patients delivered by repeat caesarean section and 2 cases resulted in abortion.

\section{DISCUSSION}

\section{Effect of uterine vessels ligation on maternal morbidity}

Placenta previa is an important cause for massive obstetric haemorrhage and causes significant maternal morbidity and mortality. Massive haemorrhage during caesarean section for placenta previa results in multiple units of blood transfusion. ${ }^{21}$ Blood loss $>2000 \mathrm{ml}$ is an important risk factor for increased maternal morbidity. ${ }^{21}$ Controlling haemorrhage during caesarean section for placenta previa is a challenging task for obstetricians. Internal iliac artery ligation and uterine artery ligation $\left(\mathrm{O}^{\prime}\right.$ Leary suture) are the two surgical procedures performed after the delivery of the placenta to control bleeding from placental bed. ${ }^{22,23}$ Uterine artery ligation reduces blood flow to uterus by $90 \% .{ }^{24}$ The blood flow reduction with internal iliac artery ligation (IIAL) varies between $40 \%$ $100 \% .^{20}$ Uterine artery ligation procedures are usually done after the delivery of the baby. ${ }^{25,26}$ Reports about the ligation of uterine vessels prior to delivery of the baby were not found in the literature. In our study, both uterine vessels (both the artery and the vein) were ligated prior to the uterine incision in 33 patients and in 19 patients unilateral ligation was done before uterine incision, subsequently opposite side vessels were ligated soon after the delivery of the baby and before the delivery of the placenta. The reduction in the blood loss and the blood transfusion were statistically significant when compared with the control group where uterine vessels were ligated after the delivery of the placenta. Bilateral uterine vessel ligation resulted in lesser blood loss than ligating one side before uterine incision. Occlusion before uterine incision is more effective in reducing blood loss as uterine incision may bleed heavily. ${ }^{19}$ As the incision site bleed is more in cases of anterior placenta previa, bilateral uterine vessel ligation prior to uterine incision is recommended for these cases.

In present study the mean blood loss was $793 \mathrm{ml}$ when both side uterine vessels were ligated, $1002 \mathrm{ml}$ blood loss when one side ligation was done before uterine incision and $2191 \mathrm{ml}$ in control group and the difference between the groups was statistically significant. There are interventional radiological methods to occlude internal iliac artery/aorta before the delivery of the baby to reduce blood loss. In a prospective study of prophylactic internal iliac artery balloon catheterization by Yeo Fan et al, the estimated blood loss was less with the occlusion group when compared to control group. The difference in intraoperative blood loss and red blood cells transfusion was statistically significant. ${ }^{19}$ In a retrospective study by Fangyuan Luo et al, intra-operative aortic balloon occlusion was done before uterine incision and recorded less blood loss. ${ }^{27}$ In present study $65.6 \%$ patients in bilateral ligation group received no blood transfusion when compared to $33.3 \%$ in control group. $41.67 \%$ patients in control group received 4 units of red blood cell transfusion and none required transfusion of more than 3 units in bilateral ligation group. Similar to our study, Yeo Fan et al also recorded a reduction in red blood cell transfusion in their study of internal iliac artery balloon catheterization. ${ }^{19}$ 
Unlike the interventional studies mentioned above, the blood vessel ligation was permanent in our study group, hence no additional procedures were required after the caesarean to control the bleeding. ${ }^{19,27}$ There was no surgery related complication in our study group. In the control group there was one case of bladder injury. Caesarean hysterectomy is a serious morbidity associated with placenta previa. In our study group there were only two cases of hysterectomy (3.84\%) among 52 patients, one was a case of placenta percreta and the hysterectomy was done with placenta in situ, as a pre-planned procedure. The second case was with multiple fibroids in a multipara and atonic bleeding continued even after the control of bleeding from placental bed. Both the cases were not due to haemostatic failures of placental bed. There were two cases (16.66\%) of hysterectomy for uncontrolled bleeding in the control group among 12 patients. In a retrospective analysis of 13 years experience at a tertiary care center by Hassan et al, hysterectomy was done in $9.1 \%$ of the cases. ${ }^{21}$ In the study of intra operative aortic balloon occlusion by Fangyuan Luo et al, hysterectomy was done in $11.6 \%$ and four of them had placenta percreta. ${ }^{27}$ Hysterectomy was $2.7 \%$ in the internal iliac balloon catheterization study by Yao Fan et al. ${ }^{19}$

In our study one patient (1.9\%) was admitted to ICU for anaesthetic complication. From control group one patient $(8.33 \%)$ had massive haemorrhage and multiple units of blood transfusion and shifted to ICU. Hassan et al in their retrospective analysis of placenta previa, documented $11.3 \%$ ICU admissions. ${ }^{21}$ In aortic balloon occlusion group, four $(9.3 \%)$ patients were transferred to ICU after caesarean section. ${ }^{27}$ Interventional radiology procedures involve two steps. After catheterization in the radiology department, the patients are shifted to the operation theatre for caesarean section. These procedures are associated with radiation exposure though small, during fluoroscopy. Arterial thrombosis is a known catheter related complication. ${ }^{27}$ Our procedure is a simple technique and can be trained easily and also cost effective.

Generally, uterine artery ligation is the first step in stepwise devascularisation in cases of uncontrolled pelvic haemorrhage and a rich collateral blood supply to the uterus will maintain the blood flow to the uterus. 55.5\% of the study group patients attended the hospital after the caesarean section for other complaints and their menstrual function was recorded as normal. $25.92 \%$ of those patients conceived. The study conducted by Dilip Kumar Dutta in patients with bilateral uterine artery ligation after the delivery of the baby, also showed similar results as ours. ${ }^{25}$

\section{Effect of uterine vessels ligation on neonates}

Placenta previa is associated with increased risk of prematurity, birth asphyxia and neonatal mortality. ${ }^{21}$ The concern was whether uterine artery ligation before the delivery of the baby could cause hypoxia in the newborn. In our study, among 52 babies born after the ligation of uterine vessels, only 6 were admitted to NICU with transient depression. They were kept in NICU for a period of 3 days or less. There were no prolonged NICU stay. There were no cases with prolonged hypoxia or long term sequelae and no neonatal mortality in our study. Magnitude of the complications associated with caesarean for placenta previa can be understood from the consent form 12 by Royal College of Obstetrics and Gynaecology. ${ }^{29}$ A multicentric trial is now being conducted from April 2017, on effect of uterine artery ligation prior to uterine incision in women with placenta previa. This study enrols patient undergoing elective caesarean section with gestational age $>34$ weeks. Results are awaited. ${ }^{28}$ The result of this study is expected to throw more information about this procedure. In our study we analysed all cases of major placenta previa irrespective of gestational age, elective/emergency caesarean section with good reduction in haemorrhage.

To conclude, bilateral uterine vessels ligation before uterine incision for major placenta previa, reduces blood loss and hysterectomy when compared to ligation of the uterine vessels after the removal of the placenta. This simple procedure can save many uterus and mothers. The neonates are also safe and the procedure does not cause any prolonged hypoxia or mortality. The simplicity of this technique enables easy training and can be practised in low resource settings also.

\section{ACKNOWLEDGMENTS}

We thank Dr. Anitha Rani (Research Advisor), Dr. Suganya (Clinical Epidemiologist), and M Jayasudha (Secretary) from Sundaram Medical Foundation, for their help in preparing this article. We also thank Dr. K. Uma, Dr. Latha, Dr. Tara and Dr. Sivagama Sundari for being involved in these surgeries.

Funding: No funding sources

Conflict of interest: None declared

Ethical approval: The study was approved by the Institutional Ethics Committee

\section{REFERENCES}

1. Khan K, Wojdyla D, Say L, Gülmezoglu A, Van Look P. WHO analysis of causes of maternal death: a systematic review. Lancet. 2006;367(9516):1066-74.

2. Machado L. Emergency peripartum hysterectomy: Incidence, indications, risk factors and outcome. North American J Med Sci. 2011; pp.358-361.

3. Chou M., Kung H, Hwang J, Chen W, Tseng J. Temporary prophylactic intravascular balloon occlusion of the common iliac arteries before cesarean hysterectomy for controlling operative blood loss in abnormal placentation. Taiwanese $\mathbf{J}$ Obstetrics Gynecol. 2015;54(5):493-8. 
4. Sheiner E, Shoham-Vardi I, Hallak M, Hershkowitz R, Katz M, Mazor M. Placenta previa: obstetric risk factors and pregnancy outcome. J Maternal-Fetal Neonatal Med. 2001;10(6):414-9.

5. Crane J, Van den Hof M, Dodds L, Armson B, Liston R. Maternal complications with placenta previa. American J Perinatol. 2000;17(2):101-6.

6. Ananth C, Demissie K, Smulian J, Vintzileos A. Relationship Among Placenta Previa, Fetal Growth Restriction, and Preterm Delivery. Obstetrics Gynecology. 2001;98(2):299-306.

7. Zlatnik M, Cheng Y, Norton M, Thiet M, Caughey A. Placenta previa and the risk of preterm delivery. J Maternal-Fetal Neonatal Med. 2007;20(10):719-23.

8. Eller A, Silver R. Optimal management strategies for placenta accrete. Int J Obstet Gynaecol. 2009;116(11):1538-9.

9. Choi S, Song S, Jung K, Oh S, Kim J, Roh, C. Antepartum Risk Factors Associated with Peripartum Cesarean Hysterectomy in Women with Placenta Previa. American J Perinatol. 2008;25(1):37-041.

10. Leerentveld R, Gilberts E, Arnold M, Wladimiroff J. Accuracy and Safety of Transvaginal Sonographic Placental Localization. Obstetrics Gynecol. 1990;76(5):759-62.

11. Sherman S, Carlson D, Platt L, Medearis A. Transvaginal ultrasound: does it help in the diagnosis of placenta previa? Ultrasound Obstetrics Gynecol. 1992;2(4):256-60.

12. Warshak C, Eskander R, Hull A, Scioscia A, Mattrey R, Benirschke K, Resnik R. Accuracy of Ultrasonography and Magnetic Resonance Imaging in the Diagnosis of Placenta Accreta. Obstetrics Gynecol. 2006;108(3):573-81.

13. Creasy RK, Resnik R, Iams J, Lockwood C, Moore T, Greene M. Placenta previa, placenta accreta, abruptio placentae, and vasa previa. Creasy and Resnik's Maternal-Fetal Medicine: Principles and Practice. 7th ed. Philadelphia, PA: Saunders; 2014: 732-742.

14. Mousa H, Walkinshaw S. Major postpartum haemorrhage. Curr Opinion Obstetrics Gynecol. 2001;13(6):595-603.

15. Hwu, Chen CP, Chen, Su TH. Parallel vertical compression sutures: a technique to control bleeding from placenta previa or accrete during caesarean section. BJOG. 2005;112:1420-3.

16. Tjalma WA, Jacquemyn Y. Compression sutures instead of emergency peripartum hysterectomy. Eur J Obstet Gynecol Reprod Biol. 2005;118:258.

17. Soyama H, Miyamoto M, Sasa H, Ishibashi H, Yoshida M, Nakatsuka M, et al. Effect of routine rapid insertion of Bakri balloon tamponade on reducing hemorrhage from placenta previa during and after cesarean section. Arch Gynecol Obstetrics. 2017;296(3):469-74.

18. Al Harbi NA, AL- Abra ES, Aiabbad NS.Uterovaginal packing. Seven years reviewin the management of postpartum haemorrhage due to placenta previa/accrete at a maternity hospital in Central Saudi Arabia. Saudi Med J. 2009;30:243-6.

19. Fan Y, Gong X, Wang N, Mu K, Feng L, Qiao F et al. A prospective observational study evaluating the efficacy of prophylactic internal iliac artery balloon catheterization in the management of placenta previa-accreta. Medicine. 2017;96(45):e8276.

20. Vedantham S, Goodwin S, McLucas B, Mohr G. Uterine artery embolization: An underused method of controlling pelvic hemorrhage. Am J Obstetrics Gynecol. 1997;176(4):938-48.

21. Abduljabbar H, Bahkali N, Al-Basri S, Al Hachim E, Shoudary I, Dause W et al. Placenta previa. A 13 years experience at a tertiary care center in Western Saudi Arabia. Saudi Med J. 2016;37(7):762-6.

22. Joshi V, Otiv S, Majumder R, Nikam Y, Shrivastava M. Internal iliac artery ligation for arresting postpartum haemorrhage. BJOG. 2007;114(3):35661.

23. O Leary JA. Uterine artery ligation in the control of post- caesarean haemorrhage. J Reprod Med. 1995;40:189-93.

24. Nayak A, Divya S, Nayak R, Mandpe P. Emergency Internal Iliac Artery Ligation in Control of Postpartum Haemorrhage: A Life saving Procedure. Int J Sci Study. 2017;4(12):183-6.

25. Dutta D, Dutta I. Management of major degree placenta previa during LSCS operation - a new surgical technique (Dutta's). Asian J Med Sci. 2013;4(2).

26. Kim J, Joung E, Lee S, Kwack J, Kwon Y. Intraoperative bleeding control during cesarean delivery of complete placenta previa with transient occlusion of uterine arteries. Obstetrics Gynecol Sci. 2015;58(6):522.

27. Luo F, Xie L, Xie P, Liu S, Zhu Y. Intraoperative aortic balloon occlusion in patients with placenta previa and/or placenta accreta: a retrospective study. Taiwanese J Obstetrics Gynecol. 2017;56(2):147-52.

28. Maged A. Effect of Uterine artery Ligation Prior to Uterine Incision in Women with Placenta Previa. Cairo university, clinicalTrials.gov Identifier: NCT03124472.

29. Caesarean Section for Placenta Praevia (Consent Advice No. 12) [Internet]. Royal College of Obstetricians \&amp; Gynaecologists. Available at: https://www.rcog.org.uk/en/guidelines-researchservices/guidelines/consent-advice-12/. Accessed on May 4, 2018.

Cite this article as: Shantha VK, Priyadarshini M, Dharshini PA, Jacob LM. Effectiveness of ligation of uterine vessels prior to uterine incision for major placenta previa on reducing maternal morbidity without increasing neonatal morbidity. Int J Reprod Contracept Obstet Gynecol 2018;7:2891-8. 